\title{
Pengembangan Buku Ajar Apresiasi Sastra Berbasis Sastra Lisan Suku Mbojo Berorientasi pada Model CIRC untuk Meningkatkan Kompetensi Mahasiswa
}

\author{
Taufik $^{1}$, M. Nur Imansyah², Eka Yulianti ${ }^{3}$ \\ 1,3 Program studi Pendidikan Bahasa dan Sastra Indonesia, STKIP Yapis Dompu \\ 2Program studi Pendidikan Teknologi Informasi, STKIP Yapis Dompu \\ E-mail: taufikbima25@gmail.com
}

\begin{tabular}{l}
\hline Article Info \\
\hline Article History \\
Received: 2021-09-20 \\
Revised: 2021-09-28 \\
Published: 2021-10-16 \\
\\
Keywords: \\
Development; \\
Literary Appreciation; \\
Mbojo Literature; \\
CIRC; \\
Competence.
\end{tabular}

\begin{abstract}
The Cooperative Integrated Reading and Composition (CIRC) learning model is one of the integrated reading and writing cooperative learning models, where students are divided into several groups to improve their comprehension skills in reading, writing, understanding vocabulary, and language arts. By utilizing the Cooperative Integrated Reading and Composition (CIRC) learning model, it aims to give students the freedom to take steps to think creatively, scientifically by collecting data from learning outcomes, then students can interpret, analyze, and finally arrive at a conclusion, so that It is hoped that student learning achievement will increase. This research is a developmental research, by developing learning tools that include: textbooks, lesson plans, worksheets and instruments for students' creative thinking skills that refer to the 4-D model (Define, Design, Develop, and Deisemination). Based on the results of descriptive analysis, the Development of Literary Appreciation Textbooks Based on Oral Literature of the Mbojo Tribe Oriented to the CIRC Model to Improve Student Competence is categorized as "good".
\end{abstract}

\begin{tabular}{l}
\hline Artikel Info \\
\hline Sejarah Artikel \\
Diterima: 2021-09-20 \\
Direvisi: 2021-09-28 \\
Dipublikasi: 2021-10-16
\end{tabular}

Abstrak

Model Pembelajaran Cooperative Integrated Reading and Composition (CIRC) merupakan salah satu model pembelajaran kooperatif terpadu membaca dan menulis, dimana mahasiswa di bagi menjadi beberapa kelompok untuk meningkatkan kemampuan pemahaman dalam membaca, menulis, memahami kosakata, dan seni berbahasa. Dengan memanfaatkan model pembelajaran Cooperative Integrated

Kata kunci:

Pengembangan; Apresiasi sastra;

Sastra Mbojo;

CIRC;

Kompetensi. Reading and Composition (CIRC) bertujuan untuk memberikan kebebasan pada mahasiswa untuk melakukan langkah-langkah berpikir kreatif, ilmiah dengan cara mengumpulkan data dari hasil pembelajaran, kemudian mahasiswa dapat menafsirkan, menganalisis, dan akhirnya sampai pada suatu kesimpulan, sehingga diharapkan prestasi belajar mahasiswa menjadi meningkat. Penelitian ini merupakan penelitian pengembangan (developmental research), dengan mengembangkan perangkat pembelajaran yang meliputi: Buku Ajar, RPS, Worksheet serta instrument kemampuan berpikir kreatif mahasiswa yang mengacu pada model 4-D (Define, Design, Develop, dan Deisemination). Berdasarkan hasil analisis deskriptif, Pengembangan Buku Ajar Apresiasi Sastra Berbasis Sastra Lisan Suku Mbojo Berorientasi pada Model CIRC untuk Meningkatkan Kompetensi Mahasiswa diketegorikan "baik”.

\section{PENDAHULUAN}

Pembelajaran apresiasi sastra untuk mahasiswa dikembangkan dengan memanfaatkan teori sastra sebagai pendekatan analisis sastra. Pembelajaran tersebut diawali dari proses membaca, memahami, sampai merefleksikan karya sastra dengan menggunakan landasan teori tertentu. Elyusra dalam (Prasetya, Pratiwi, and Widiati 2017) menjelaskan bahwa pembelajaran sastra dimaksudkan sebagai pembelajaran yang membekali mahasiswa dengan pengetahuan sastra dalam berbagai tatarannya. Berdasarkan hal tersebut, tujuan pembelajaran sastra tidak hanya berhenti pada aspek kognitif (pengetahuan), tetapi juga aspek afektif (kepribadian) dan aspek psikomotor, Matakuliah apresiasi sastra merupakan matakulilah wajib yang harus ditempuh oleh mahasiswa Program Studi Pendidikan Bahasa dan Sastra Indonesia STKIP Yapis Dompu semester V dengan bobot 2 SKS. Dengan mengikuti matakuliah ini mahasiswa diharapkan dapat menguasai konsep sastra sebagai landasan untuk mengapresiasi karyakarya sastra Indonesia, khususnya mengapresiasi karya-karya sastra lisan suku Mbojo. Sastra lisan suku Mbojo merupakan warisan budaya 
masyarakat, karena didalamnya tercermin pikiran, perasaan dan cita-cita masyarakat pendukungnya dan menjadi kekayaan budaya bangsa yang merupakan salah satu bentuk eskpresi budaya daerah yang sangat berharga, bukan hanya menyimpan nilai-nilai budaya dari masyarakat tradisional suku Mbojo. Namun lebih dari itu, yakni menjadi akar budaya dari masyarakat tersebut.

Selanjutnya (Taufik 2020), mengemukakan bahwa sastra lisan suku Mbojo merupakan pencerminan situasi, kondisi, dan tata krama masyarakat pendukungnya. Keberadaan sastra lisan suku Mbojo di berbagai daerah, khusunya daerah Kabupaten Bima Provinsi Nusa Tenggara Barat yang hingga saat ini masih eksis di tengah masyarakat. Kenyataan ini menunjukkan bahwa sastra lisan suku Mbojo tersebut masih tetap di nikmati, diapresiasi, dan diterima oleh masyarakat serta menjadikannya sebagai bagian dari kebudayaan. Berdasarkan hal tersbut peneliti tertarik untuk mengembangkan buku ajar berbasis sastra lisan suku Mbojo.

Buku Ajar tersebut sebagai penunjang pada perkuliah apresiasi sastra berbasis sastra lisan suku Mbojo dapat memanfaatkan Model Pembelajaran Cooperative Integrated Reading and Composition (CIRC). Model tersebut cocok digunakan di Program Studi Bahasa dan Sastra Indonesia, karena dapat memaksimalkan waktu belajar dan mengembangkan kompetensi para mahasiswa. Model Pembelajaran Cooperative Integrated Reading and Composition (CIRC) adalah salah satu model pembelajaran kooperatif terpadu membaca dan menulis, dimana mahasiswa di bagi menjadi beberapa kelompok untuk meningkatkan kemampuan pemahaman dalam membaca, menulis, memahami kosakata, dan seni berbahasa. Menurut Uno dan Muhamad dalam (Taufik, Erwin 2020) Model Cooperative Integrated Reading and Composition (CIRC) merupakan salah satu tipe model pembelajaran kooperatif yang merupakan komposisi terpadu membaca dan menulis secara kooperatif (kelompok), yaitu membaca materi yang diajarkan dari berbagai sumber dan selanjutnya menuliskannya ke dalam bentuk tulisan yang dilakukan secara kooperatif.

\section{METODE PENELITIAN}

Penelitian ini merupakan penelitian pengembangan (developmental research), dengan mengembangkan perangkat pembelajaran yang meliputi: Buku Ajar RPS, Worksheet serta instrument kemampuan berpikir kreatif mahasiswa yang mengacu pada model 4-D Model, Penelitian ini dilaksanakan pada mahasiswa Program Studi Pendidikan Bahasa dan Sastra Indonesia semester V (lima) dengan jumlah 24 orang mahasiswa, tahun pembelajaran 2020/2021, Model pengembangan yang akan digunakan untuk mengembangkan perangkat pembelajaran dalam penelitian ini adalah model Thiagarajan yang dikenal dengan Four-D Models (Model 4-D), Instrument penelitian yang digunakan dalam penelitian ini yaitu:

a. Lembar validasi perangkat pembelajaran Lembar validasi perangkat pembelajaran terdiri dari lembar validasi RPS, Lembar Validasi Worksheet, Lembar Validasi soal Tes kompetensi, Lembar Validasi Buku Ajar.

b. Worksheet

Worksheet digunakan untuk memperoleh informasi berkaitan dengan kegiatan belajar mahasiswa selama uji coba.

a. Lembar observasi kemampuan dosen mengelola pembelajaran

Instrumen ini digunakan untuk mengamati beberapa aspek kemampuan dosen, yang berkaitan dengan tahapan model CIRC

b. Angket respon mahasiswa

Respon mahasiswa adalah tanggapan mahasiswa setelah diterapkan perangkat pembelajaran menggunakan model CIRC untuk meningkatkan kreativitas mahasiswa.

c. Soal tes

Soal tes digunakan untuk memperoleh informasi tentang hasil belajar secara klasikal. Bentuk tes adalah uraian dan penilaian bergantung pada kesulitan soal. Agar tes yang disusun berkualitas memadai, maka diperlukan analisis butir. Analisis butir tes meliputi uji validitas, uji reliabilitas, dan uji sensitivitas

Adapun teknik analisis data yang digunakan dalam penelitian ini diantaranya:

a. Analisis Data Validasi

Data hasil penilaian para ahli untuk tiaptiap perangkat pembelajaran dianalisis dengan mempertimbangkan masukan, komentar, dan saran-saran dari validator. Hasil analisis tersebut dijadikan sebagai pedoman untuk merevisi perangkat pembelajaran. Data hasil penilaian dari validator dianalisis berdasarkan pada rata-rata skor:

$1,00 \leq$ Rata-rata $\leq 1,50$ sangat tidak baik

$1,50<$ Rata-rata $\leq 2,50$ tidak baik

$2,50<$ Rata-rata $\leq 3,50$ baik 


\section{$3,50<$ Rata-rata $\leq 4,00$ sangat baik}

b. Analisis Data Uji Coba

1) Analisis data kemampuan dosen mengelola pembelajaran

Data tentang kemampuan dosen mengelola pembelajaran dianalisis dengan menggunakan statistik deskriptif yaitu dengan skor rata-rata. Adapun pendeskripsian skor rata-rata tingkat kemampuan dosen adalah sebagai berikut:

$1,0 \leq$ Rata-rata $\leq 1,50$ sangat tidak baik

$1,50<$ Rata-rata $\leq 2,50$ tidak baik

$2,50<$ Rata-rata $\leq 3,50$ baik

$3,50<$ Rata-rata $\leq 4,00$ sangat baik

2) Analisis data aktivitas mahasiswa

Data hasil pengamatan aktivitas mahasiswa dalam pembelajaran dianalisis dengan persentase. Persentase pengamatan aktivitas mahasiswa yaitu frekuensi setiap aspek pengamatan dibagi dengan total frekuensi semua aspek pengamatan dikalikan 100\%. Penentuan kesesuaian aktivitas mahasiswa berdasarkan pada alokasi waktu dalam rencana pembelajaran (selanjutnya disebut waktu ideal) dengan toleransi $10 \%$ diambil berdasarkan taraf kesalahan dalam pengambilan keputusan yang diperbolehkan untuk penelitian-penelitian sosial dan pendidikan.

3) Data Respon Mahasiswa

Data tentang respon mahasiswa diperoleh melalui angket yang dianalisis dengan menggunakan statistik deskriptif, respon mahasiswa dihitung dengan rumus:

$\frac{\text { Iumlah respon positif untuk setiap aspek }}{\text { Iumlah seluruh siswa }} \times 100 \%$

4) Analisis Data Tes Hasil Belajar

Data yang diperoleh dari THB selanjutnya diolah untuk menentukan validitas butir tes, sensitivitas butir tes, dan reliabilitas tes.

\section{HASIL DAN PEMBAHASAN}

\section{A. Hasil Penelitian}

Hasil penelitian ini disusun berdasarkan perolehan data hasil validasi serta ujicoba perangkat pembelajaran yang dilaksanakan di STKIP Yapis Dompu Tahun 2021 pada Mahasiswa program Studi Pendidikan Bahasa dan Sastra Indonesia di STKIP Yapis Dompu. Hasil yang dicapai dalam penelitian ini diuraikan sebagai berikut: a. Hasil Validasi RPS

Grafik dibawah ini, menunjukan bahwa ratarata penilaian setiap indikator untuk semua aspek berada pada kategori baik dan sangat baik, sehingga dapat dinyatakan bahwa RPS dalam draft 1 bernilai valid. Secara umum, validator menyatakan bahwa RPS bernilai sangat baik dan dapat digunakan dengan catatan sedikit revisi. Selanjutnya, dibawah ini akan dipaparkan hasil validasi Workhseet.

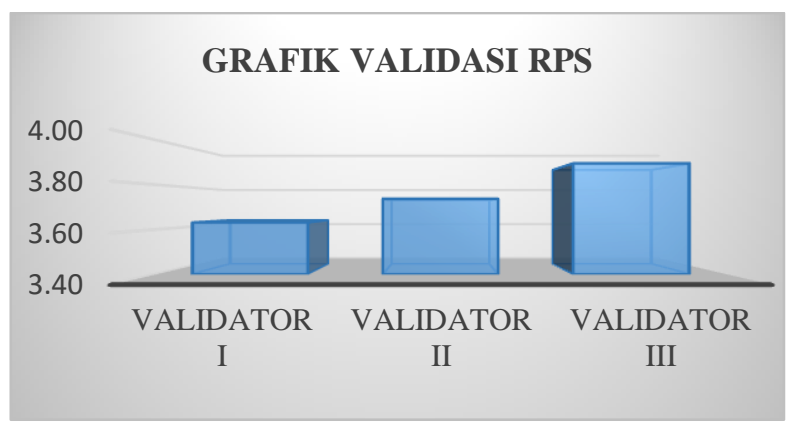

Gambar 1. Grafik Hasil Validitas RPS

b. Hasil Validasi Workhseet

Grafik dibawah ini, menunjukan bahwa ratarata setiap indikator pada semua aspek yang dinilai berada pada kategori baik dan sangat baik. Hasil penilaian secara umum terhadap Worksheet menunjukkan bahwa Worksheet berkualitas sangat baik dan dapat digunakan dengan catatan sedikit revisi. Selanjutnya, dibawah ini akan dipaparkan hasil validasi Soal Tes Mahasiswa

\section{GRAFIK VALIDASI WORKSHEET}

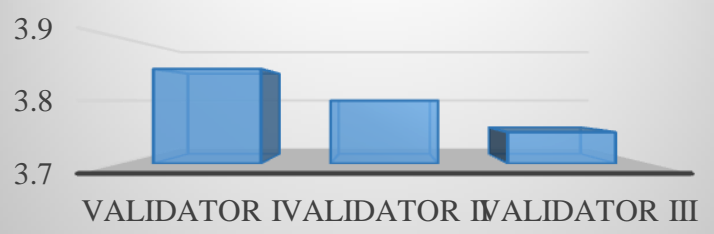

Gambar 2. Grafik Hasil Validitas Worksheet

c. Hasil Validasi Soal Tes Mahasiswa

Grafik berikut, menunjukan instrumen validasi soal Tes Kompetensi Mahasiswa yang diberikan kepada validator berisi tentang penilaian dan komentar saran-saran perbaikan. Hasil penilaian validator dapat dilihat pada grafik, bahwa rata-rata setiap indikator pada semua aspek yang dinilai berada pada kategori baik dan sangat baik. Hasil penilaian secara umum terhadap soal tes menunjukkan bahwa soal tes berkualitas 
sangat baik dan dapat digunakan dengan catatan sedikit revisi. Selanjutnya, dibawah ini akan dipaparkan hasil validasi buku ajar.

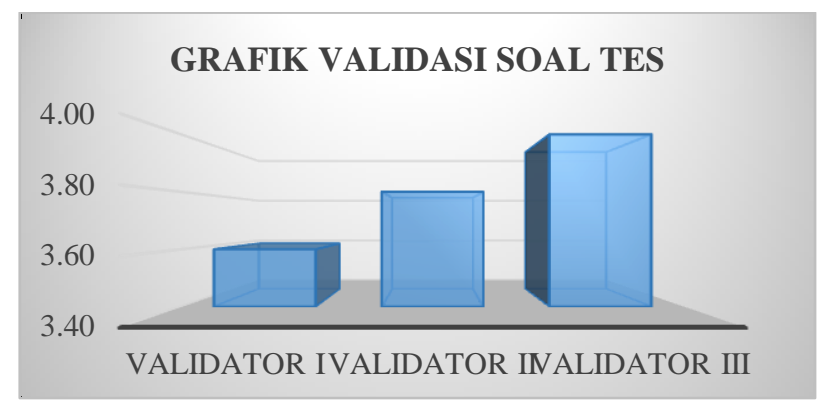

Gambar 3. Grafik Hasil Validitas Soal Tes

\section{d. Hasil Validasi Buku Ajar.}

Grafik berikut menunjukan instrumen validasi buku ajar yang diberikan kepada validator berisi tentang penilaian dan komentar saransaran perbaikan. Hasil penilaian para validator dapat dilihat pada grafik yang menunjukkan bahwa rata-rata setiap indikator pada semua aspek yang dinilai berada pada kategori baik dan sangat baik. Hasil penilaian secara umum terhadap buku ajar menunjukkan bahwa buku ajar berkualitas sangat baik dan dapat digunakan dengan catatan sedikit revisi.

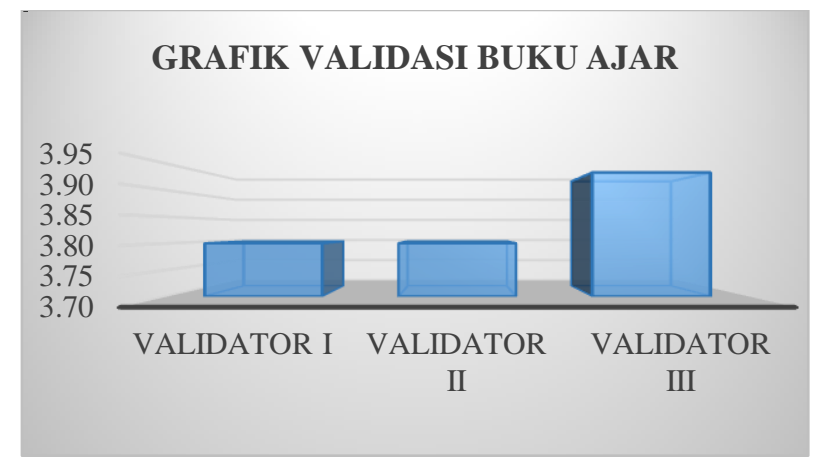

\section{B. Pembahasan}

Beberapa hal yang dapat dicatat dalam penelitian ini berdasarkan temuan pada saat validasi ahli dan uji coba lapangan, diuraikan sebagai berikut: Hasil penilaian ahli/validator seperti yang diuraikan pada Bab III menunjukkan bahwa, perangkat pembelajaran yang terdiri dari: RPS, Worksheet, dan THB ditinjau dari indikator format, bahasa, isi, dan/atau ilustrasi dikategorikan baik. Hal ini ditunjukkan dengan rata-rata skor penilaian ahli terhadap RPS, Worksheet, dan THB lebih dari 3,50. Secara umum, Buku Ajar Apresiasi Sastra Berbasis Sastra Lisan Suku Mbojo Berorientasi pada Model CIRC untuk Meningkatkan Kompetensi Mahasiswa yang dikembangkan berada pada kategori "sangat baik" dan dapat digunakan (sedikit revisi).

Berdasarkan kategori kemampuan Peneliti/Dosen mengelola pembelajaran seperti yang diuraikan pada bagian sebelumnya, hasil analisis data setiap aspek kemampuan Peneliti/Dosen mengelola pembelajaran yang diamati/dinilai untuk 2 (dua) kali pertemuan mengindikasikan bahwa kegiatan pembelajarannya efektif. Hal ini ditunjukkan dengan rata-rata skor pada setiap aspek kemampuan Peneliti/Dosen mengelola pembelajaran mencapai kategori minimal baik. Buku Ajar Apresiasi Sastra Berbasis Sastra Lisan Suku Mbojo Berorientasi pada Model CIRC untuk Meningkatkan Kompetensi Mahasiswa mengharuskan mahasiswa untuk aktif dalam pembelajaran. Sehingga, dominasi Peneliti/Dosen dapat berkurang. Hal ini sejalan dengan teori konstruktivis dimana teori ini menganjurkan agar mahasiswa lebih berperan aktif dalam pembelajaran atau yang lebih dikenal dengan pembelajaran yang berpusat pada mahasiswa. Hasil analisis data aktivitas mahasiswa menunjukkan bahwa, persentase aktivitas mahasiswa dari setiap aspek yang diamati selama 2 (dua) kali pertemuan sesuai dengan alokasi waktu dalam RPS dan sesuai dengan kriteria waktu ideal, Berdasarkan kriteria keefektifan aktivitas mahasiswa seperti yang telah diuraikan pada Bab III, menunjukkan bahwa Aspek ke-1 tentang "Memperhatikan/ mencatat/ bertanya/ menjawab penjelasan atau pertanyaan dari Peneliti/ Dosen saat orientasi dan pembekalan" untuk semua RPS berada pada kriteria waktu ideal. Aspek ke-2 tentang "menyelesaikan Worksheet secara individu" untuk semua RPS berada pada kriteria waktu ideal. Aspek ke-3 tentang "menyelesaikan Worksheet melalui diskusi kelompok" untuk semua RPS berada pada kriteria waktu ideal. Aspek ke-4 tentang "berperan serta dalam kegiatan presentasi" untuk semua RPS berada pada kriteria waktu ideal. Aspek ke-5 tentang "mengikuti penarikan kesimpulan" untuk semua RPS berada pada kriteria waktu ideal. Aspek ke-6 tentang "prilaku yang tidak relevan" untuk semua RPS berada pada kriteria waktu ideal. Berdasarkan data di atas dapat disimpulkan bahwa aktivitas mahasiswa dikategorikan "efektif".

Sesuai dengan yang telah diuraikan pada Bab III tentang respon mahasiswa terhadap 
pembelajaran, hasil analisis data respon mahasiswa terhadap komponen dan kegiatan pembelajaran Buku Ajar Apresiasi Sastra Berbasis Sastra Lisan Suku Mbojo Berorientasi pada Model CIRC untuk Meningkatkan Kompetensi Mahasiswa menunjukkan lebih dari 70\% mahasiswa memberikan respon dengan kategori "positif" untuk tiap-tiap aspek.

Hasil analisis validitas butir tes, reliabilitas tes, dan sensitivitas butir tes menunjukkan bahwa semua butir tes hasil belajar topik logika memiliki validitas cukup dan tinggi, hal ini sejalan dengan yang dikemukakan Arikunto bahwa suatu butir dinyatakan valid jika koefisien validitas butir tersebut diinterpretasikan minimal cukup. Reliabilitas tes hasil belajar termasuk dalam kategori tinggi, dan semua butir tes sensitif terhadap pembelajaran. hal ini juga sejalan dengan yang dikemukakan Ratumanan dan Laurens bahwa suatu tes ddinyatakan reliabel jika koefisien reliabilitas tes tersebut diinterpretasikan minimal cukup dan suatu butir tes dikatakan sensitif apabila indeks sensitivitasnya berada antara 0,00 dan 1,00. Sehingga THB dikategorikan "baik", Berdasarkan kriteria ketuntasan hasil belajar yang telah diuraikan pada Bab III, ketuntasan belajar mahasiswa secara individual mencapai 24 mahasiswa atau $85 \%$ mahasiswa tuntas secara individual. Oleh karena itu, ketuntasan belajar mahasiswa dinyatakan "tuntas".

Berdasarkan pembahasan di atas dan apa yang telah diuraikan pada bagian sebelumnya, perangkat pembelajaran ini dapat disimpulkan memenuhi kategori baik. Sebab keenam syarat terpenuhi: (a) valid berdasarkan penilaian ahli, (b) kemampuan Peneliti/ Dosen dalam mengelola pembelajaran efektif, (c) aktifitas mahasiswa efektif, (d) respon mahasiswa positif terhadap pembelajaran, dan (e) THB valid, reliable, dan sensitive, (f) hasil belajar mahasiswa secara klasikal tuntas. Oleh karena itu, Buku Ajar Apresiasi Sastra Berbasis Sastra Lisan Suku Mbojo Berorientasi pada Model CIRC untuk Meningkatkan Kompetensi Mahasiswa memenuhi kategori "baik".

\section{SIMPULAN}

Berdasarkan tujuan dan hasil penelitian dapat disimpulkan bahwa Prosedur Pengembangan Buku Ajar Apresiasi Sastra Berbasis Sastra Lisan Suku Mbojo Berorientasi pada Model CIRC untuk Meningkatkan Kompetensi Mahasiswa menggunakan model 4-D yang dimodifikasi menjadi tiga tahap sesuai dengan tujuan penelitian; yaitu: (a) Tahap Pendefinisian. Kegiatan yang dilakukan dalam tahap ini adalah analisis awal-akhir, analisis mahasiswa, analisis konsep, analisis tugas, dan spesifikasi tujuan pembelajaran; (b) Tahap Perancangan. Hasil kegiatan pada tahap ini yaitu rancangan awal perangkat pembelajaran berupa RPS, Worksheet, dan THB; (c) Tahap Pengembangan. Hasil kegiatan pada tahap ini yaitu Draft II, uji keterbacaan menghasilkan Draft III, dan kegiatan akhir yaitu uji coba Draft III, data hasil uji coba dianalisis dan dapat disimpulkan bahwa, perangkat pembelajaran berada pada kategori "baik", Berdasarkan hasil analisis deskriptif, Buku Ajar Apresiasi Sastra Berbasis Sastra Lisan Suku Mbojo Berorientasi pada Model CIRC untuk Meningkatkan Kompetensi Mahasiswa diketegorikan "baik", karena keenam kriteria perangkat pembelajaran yang baik terpenuhi, yaitu: (a) Valid menurut validator, (b) Efektif untuk kemampuan Peneliti/Dosen mengelola pembelajaran, (c) Efektif untuk aktivitas mahasiswa dalam pembelajaran, (d) Positif untuk respon mahasiswa terhadap pembelajaran, (e) Valid, reliabel, dan sensitif untuk THB, dan (f) Ketuntasan belajar secara klasikal tercapai

\section{DAFTAR RUJUKAN}

Afriani, R. (2015). Pengaruh Persepsi Siswa Tentang Kompetensi Kejuruan, Penguasaan Soft Skill, Dan Kematangan Karir Terhadap Kesiapan Kerja Siswa Kelas XII Akuntansi SMK Negeri 2 Magelang Tahun Ajaran 2014/2015. Economic Education Analysis Journal, 4(2), 453-468.

Epina, H. (2018). Pengaruh Penggunaan Model Cooperative Learning Tipe Cooperative Integrated Reading and Composition Terhadap Peningkatan Pemahaman Konsep Peserta Didik. Jurnal Pendidikan dan Pembelajaran EDUCARE, 16(2), 1-80.

Machali, I. 1970. Kebijakan Perubahan Kurikulum 2013 dalam Menyongsong Indonesia Emas Tahun 2045. Jurnal Pendidikan Islam, 3(1), 71. https://doi.org/10.14421/jpi.2014.31.7194

Prasetya, Y. (2017). Pengembangan Buku Penunjang. Jurnal Pendidikan, 2(6), 751755. 
Pratama, D. R. (2017). Keunikan Budaya Minangkabau dalam Novel Tenggelamnya Kapal Van Der Wijck Karya Hamka dan Strategi Pemasarannya dalam Konteks Masyarakat Ekonomi Asean. The 1st Education and Language International Conference Proceedings, 221-235.

Ria Intani. (2016) Fungsi Ngarot untuk Masyarakat Lelea. Patanjala, 8(1), 37-52.

Taufik, Erwin, \& Husnul Khatimah. (2020). Pengembangan Perangkat Pembelajaran Model CIRC pada Mata Kuliah Apresiasi Sastra "Mantra Mbojo" untuk Melatih Kemampuan Berpikir Kreatif Mahasiswa. JIIP - Jurnal Ilmiah Ilmu
Pendidikan, 3(3), 635-641. Retrieved from http://jiip.stkipyapisdompu.ac.id/jiip/inde x.php/JIIP/article/view/171

Taufik, Erwin, \& Husnul Khatimah. (2020). Model Pembelajaran CIRC pada Mata Kuliah Apresiasi Sastra "Mantra Mbojo" untuk Meningkatkan Kreativitas Mahasiswa. Ainara Journal (Jurnal Penelitian Dan PKM Bidang Ilmu Pendidikan), 1(2), 62-70. https://doi.org/10.1234567/ainarajournal .v1i2.15

Taufik. (2020). Mantra Mbojo (Sebagai Bahan Ajar pada Mata Kuliah Apresiasi Sastra) (E. Yulianti (ed.); 1st ed.). Nathan Indonesia. 